\title{
Improvement of Mathematics Teacher Performance Through Academic Supervision With Collaborative Approaches
}

\author{
Isa Anshori, Suwidiyanti²
}

\section{ARTICLE INFO \\ Article History: \\ Received 21.12.2019 \\ Received in revised \\ form 11.05.2020 \\ Accepted \\ Available online \\ 01.07.2020}

\begin{abstract}
This study aims to understand the improvement of mathematics teacher performance in learning through academic supervision with a collaborative approach. Using school action research; two cycles are carried out, with 4 stages, namely: Planning, Implementation, Observation, and Reflection. The research subjects were determined purposively, consisting of six mathematics teachers class Ten, Eleven, and Twelve in a well-known high school in Indonesia. Data collection is done through focused observation, in-depth interviews and documentaries, and using academic supervision instruments. The results showed that the use of collaborative approaches in effective academic supervision could improve the performance of mathematics teachers in high schools. This increase in performance was seen in all the tasks and responsibilities of teachers, starting from preparing and developing learning plans $(19.40 \%)$, implementing the learning process $(22.40 \%)$, evaluating the process and learning outcomes $(4.55 \%)$, implementing the follow-up activities of student assessment results $(33.00 \%)$, to complete the administration of learning $(5.84 \%)$. This improvement occurred because the supervision carried out in schools was carried out collaboratively, with full peer, involving various components of the school.
\end{abstract}

(C) IJERE. All rights reserved

Keywords:

Mathematics teacher performance, academic supervision, collaborative

The biggest challenge faced by the Indonesian Ministry of Education in entering the era of the industrial revolution 5.0 is not only equality, fulfillment of access, and educational infrastructure, but also the quality of teachers and graduates who are able to compete with the demands of the times. Competent teachers become the main prerequisite to realize the implementation of quality education. They are the main actors and the frontlines in implementing teaching and learning in schools.

Teacher performance is very influential on the success of the education and learning process in schools (Lalupanda, 2019). Teacher performance can be seen from how much the required competencies can be fulfilled. Teacher performance in learning related to the ability of teachers to plan, implement and assess learning, both related to the process and the results. The main task component is then translated into measurable performance indicators.

The Teacher Competency Test (UKG) results show that the average teacher competency until 2017 is below 70 out of a maximum score of 100 at all levels (Rahadian and Paramita, 2018; Jamal, 2018). This indicates that teacher performance cannot be proud of. Provisional allegation of the impropriety factor is because many teachers do not meet academic qualifications. However, the allegation is disputed with the results of the 2018 survey. They are graduates of the Teacher Professional Education Program (PPG) (Kelana, 2020). The low ability of the teacher is also correlated to the quality of students, especially related to the ability to read, mathematics and science (Kelana, 2020).

Mathematics teachers have a big role in determining the quality of students because mathematics teachers who are still not optimal will have an impact on the mathematical abilities of students who have not reached the minimum competency standard. Mathematics is an important science, which is related to other sciences that use mathematics in it. Mathematics is studied at every

Corresponding e-mail: isaanshori67@gmail.com; orcid.org/0000-0002-6729-642X, The State Islamic University Sunan Ampel, Surabaya, Indonesia; ${ }^{2}$ Graduate Program of Islamic Education Management, Muhammadiyah University of Sidoarjo, Indonesia 
level of education and is one of the subjects tested in the National Examination (UN) - even though starting in 2020 the National Examination in schools/madrasas is deleted. The results of the 2019 high school and vocational high school UN show an increase in the average of mathematics subjects in the natural science majors, from an average of 37.25 to 39.39, up 2.04\%. Even though it has increased, the average value is still very lacking because it does not meet the minimum completeness standard set, which is equal to 55.00 (Sindo, 2019). The low value of mathematics UN is probably one of the factors is the teacher's performance is not optimal.

To measure the performance of mathematics teachers, control is needed in the form of supervision or supervision by supervisors and school principals. This supervision aims to help the teacher so that all activities that have been programmed, especially related to the main task of the teacher can run effectively in accordance with what has been planned. Supervision of an education supervisor is trying to improve the performance of teachers in carrying out their professional duties (Fathurrohman and Suryana, 2011:32).

Supervision is the duty of school principals and school supervisors. Principal's leadership through the provision of supervision services to teachers is one of the organizational variables that can affect teacher performance. Supervision of school principals has a very big influence, micro can improve the performance of teachers, which leads to an increase in the quality of the learning process, and at a macro level there is an increase in the quality of Indonesian human resources as a whole (Hadis and Nurhayati, 2014: 36).

School supervisors also have the main task of conducting academic supervision. However, supervision that has been done by school supervisors so far tends to focus on administrative aspects, not much is determined by the quality of learning. In fact, academic supervision is carried out aimed at improving the learning process. "School leaders need resources to build capacity, particularly in accommodating the new time demands of teacher evaluation" (Lavigne and Chamberlain, 2017). Mulkeen called "Teacher professional development remains one of the key elements used by education officials to ensure the adequate preparation of teachers for the teaching profession" (Lawrence and Bouchamma, 2014).

Various previous research results indicate that academic supervision conducted by the principal has a great influence on improving teacher performance. Hardono, Haryon, and Amin Yusuf (2017) showed an effect of 7.2\%. Ahmad Ramadhan (2017) shows that the implementation of academic supervision by school supervisors and school principals has a significant influence on teacher work performance.

In contrast to the research, Basri (2017) proved that there was no strong relationship between the principal's leadership and the achievement of the quality of students' academic graduates. Similarly, Faridah (2017), proves that there is no relationship between leadership using technology and school academic achievement.

According to Ajasan (2016), the implementation of academic supervision by the school principal was arranged referring to the identification of problems faced by teachers based on the results of the previous year's supervision (Jumadiah, Nurdia, Rahmi, and Rhoni, 2016; Maya Putri, M.A., and Khairuddin, 2016). Meanwhile and Aulia Riski (2019) recommended that the implementation of academic supervision by school principals be effective and needed conceptual, interpersonal and technical skills.

Research by Dalawi, Zakso, and Radiana (2019), recommends the need for academic supervision by school supervisors to improve teacher professionalism. Fahmi (2018) prove the implementation of academic supervision that has been carried out by supervisors is not effective for increasing teacher competency, because of the many teachers that must be fostered by supervisors. Merukh and Sulasmono (2016) his research results showed that the implementation of supervision of principals has not been carried out in accordance with the principles of supervision performance. Research by Leniwati (2017) recommend the School Literacy Movement (GLS) to improve teacher performance. Alghifari's (2016) research shows the importance of improving the quality of institutions to improve teacher performance. Susetya (2017) proves that continuous academic supervision can 
improve the ability of teachers in making syllabus and lesson plans. Research Kurniawan (2018) found the need for academic supervision based on conditions and needs to improve teacher quality. Guntoro (2016) provided input on the importance of developing the WEB-based Academic Supervision Model. Majid's (2018) research shows there is an increase in the competency of principals in academic supervision through coaching.

Various results of these studies indicate that there are still differences in the implementation of supervision in schools so the results are also different. Then how is the effective implementation of academic supervision in order to really improve teacher performance, which then has an impact on improving the quality of learning and student learning outcomes? The following study seeks to find these solutions, namely conducting academic supervision by applying a collaborative approach to improve teacher performance. Performance measurements were carried out for all mathematics subject teachers in a well-known senior high school in Sidoarjo, East Java, institutionally having the highest ranking nationally, namely three times in a row to achieve outstanding school rankings.

\section{Situation of the Problem}

Based on preliminary observations, and the recognition of teachers who have been supervised by the school supervisor, supervision has not been followed up by the school. After supervised, the supervisor gives an assessment and points out the weaknesses or weaknesses of the teacher. But there is no further academic supervision to find out whether or not improvements have been made. There should be continued academic supervision to the same teacher to find out the effectiveness of academic supervision in order to improve teacher performance.

In addition, school supervisors use a direct, individual approach in carrying out their academic supervision tasks. Supervisors visit teachers who are teaching in class, observe their performance, then carry out assessment activities, and tend to blame. This supervision approach is felt to be less effective, because it is more judging rather than providing a solution. It is better if academic supervision is carried out by means of assistance or collaborative and discussion is carried out flexibly, so that it can help teachers to reflect on their performance well.

Other problems that occur in schools related to the performance of mathematics teachers, from the results of preliminary observations shows that there are still mathematics teachers who always teach using the lecture method, rarely use interesting and interactive learning media in carrying out the learning and assessment process, and follow-up assessments are not in accordance with the existing administrative format. Considering the conditions described, academic supervision using a collaborative approach is needed to improve the performance of mathematics teachers' performance.

\section{Aim of the Study}

The purpose of this study was to understand and find improvements in mathematics teacher performance through the implementation of academic supervision with a collaborative approach. In order to maintain the reliability of the findings, answers to the following questions were sought: how was the performance of mathematics teachers before academic supervision with a collaborative approach and after a collaborative approach was applied, how they differed, how they improved.

\section{METHOD}

This research is a School Action Research that uses a qualitative approach, which is a scientific method that is carried out systematically through cycles with the aim of analyzing social situations, understanding problems, and then finding solutions in the form of actions to be able to help improve social situations, and to innovate (Sugiyono, 2015)

The researcher together with the supervisor designs and conducts the research in two cycles. Each cycle consists of four stages, namely (1) planning, by preparing an academic supervision instrument. Plans are made referring to the results of initial reflective observations. (2) The 
implementation phase is carried out with actions in accordance with the steps of academic supervision and explains how to properly manage teaching and learning activities. Next, the teacher is asked to show the learning instruments they have. The supervisor then evaluates the learning device. (3) In the Observation stage, the researchers make observations based on the results of the action. (4) The last stage is a reflection of the results of observations regarding the results of actions and the decision to take the next cycle of actions. In the first cycle the researchers applied academic supervision with a non-directive approach, whereas in the second cycle the collaborative approach was applied.

This research was conducted at SMA Muhammadiyah 2 Sidoarjo in the odd semester of the 2019/2020 Academic Year. This is a superior school in East Java, Indonesia, which has won outstanding ranking three times in a row. The research subjects are all mathematics teachers who teach both at grade X, XI, or XII. The number of mathematics teachers in this high school is as many as 6 people with characteristics such as high motivation to reflect on their performance, work collaboratively, and share experiences and solutions with colleagues.

\section{Material}

Data collection techniques through in-depth observation, focused interviews and documentation. While the data collection tool uses the supervision instruments, academic supervision guidelines, and documentation instruments (photos, etc.).

\section{Data Analyses}

The data that has been obtained are analyzed by applying qualitative and quantitative analysis. Changes in teacher behavior in learning can be explained by qualitative analysis, while the success of teachers in improving their performance can be known by quantitative analysis.

In this action research, the benchmark of success indicators used by the supervisor is if the average percentage of success of the supervised mathematics teacher increases. Guidelines on the value of success of a teacher is greater or equal to $(\geq) 75$. Dimensions of mathematics teacher performance that are used as indicators of success include: (1). teacher performance in completing teacher administration, (2). Teacher's work achievements in developing and compiling learning plans, (3) Teacher's work achievements in carrying out the learning process, (4) Teacher's work achievements in conducting and processing students' learning outcomes assessments, (5) Teacher's work achievements in implementing follow-up participant assessment results students, in the form of remedial and enrichment.

Quantitative data in the form of a percentage becomes the basis or reference, which is then converted and translated into qualitative data using the following criteria:

Table 1: Qualification of Teacher Performance Evaluation in Learning

\begin{tabular}{ccc} 
School Interval & Predicate & Descriptions \\
\hline $90-100$ & A & Very Good \\
$76-89$ & B & Good \\
$61-75$ & C & Average \\
$<60$ & D & Less \\
\hline
\end{tabular}

Assessment of supervision results is calculated in cycle I, and cycle II using the following formula and classification:

$$
\text { Grade }=\frac{\text { Planning }+ \text { Im plementation }+ \text { Evaluation }+ \text { Follow }- \text { up }+ \text { DocumentCompletness }}{5} \times 100
$$

\section{FINDINGS}

Academic supervision conducted in high school is not directly carried out by the principal. The headmaster shares academic supervision tasks with senior teachers who are professional. The school principal issues a decree attached to the distribution of the names of the supervising teachers and who the 
teachers will be supervised, the division of tasks is based on allied subjects, so that each supervisor only supervises 5 or 6 teachers. The math teacher profiles are supervised as follows:

Table 2: A description of gender, age, etnicity and educational background of the supervised teachers

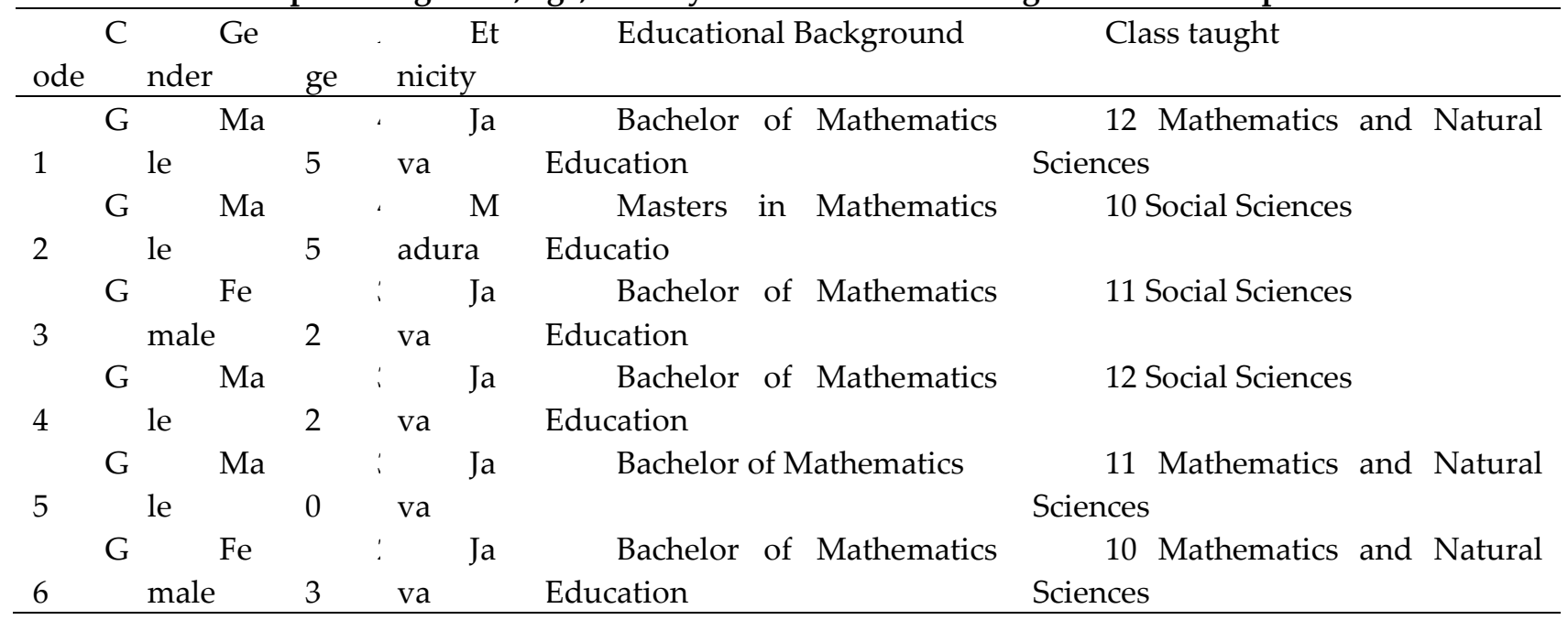

Teacher performance is assessed by taking into account the indicators shown by the teacher in carrying out his duties as a professional teacher, namely planning learning, carrying out the learning process, carrying out the assessment process and learning outcomes, carrying out follow-up assessment results, and completing teacher administration documents.

The following is a description of the results of school action research related to the supervision process in cycle I and cycle II.

\section{Academic Supervision Findings of Mathematics Teachers Related to Teacher's Work Achievement} in Learning in Cycle I.

Teacher performance in supervised learning consists of teacher performance in completing teacher administration, teacher performance in developing and developing learning plans, teacher performance in implementing learning, teacher performance in evaluating student learning outcomes, and teacher performance in implementing follow-up activities to assess students learning results. Teacher performance in learning is observed and measured using supervision instruments.

Following are the stages of academic supervision of mathematics teachers in learning in cycle I:

1) Planning

$>$ Socialization of the aims and scope of research to teachers

$>$ Discussion of teacher performance in ideal learning

$>$ Plans for the supervision to be carried out in August 2019.

2) Implementation

$>$ The supervisor explains the purpose and objectives of school action research

$>$ The supervisor explained the importance of developing teacher competency and the quality of learning in schools.

$>$ The supervisor explains the teacher's performance in learning to be supervised.

$>$ Teachers are asked to explain the obstacles experienced when managing teaching and learning activities

> Supervisors discuss with the mathematics teacher forum to find a solution to the common problem because all supervised members are mathematics teachers

$>$ A forum between supervised mathematics teachers contributing ideas or ideas that become solutions to teachers who have problems. 
$>$ The supervisor and the mathematics teachers together concluded the day's activities.

> Supervisor explained that supervision will be held related to teacher performance in learning

3) Observation

The Supervisor makes observations through academic supervision conducted in the classroom by using the observation sheet that has been prepared and then assessing it using the evaluation instrument format. At this stage, the teacher does the teaching and learning process. Based on observations by supervisors in the first cycle, the following results were obtained:

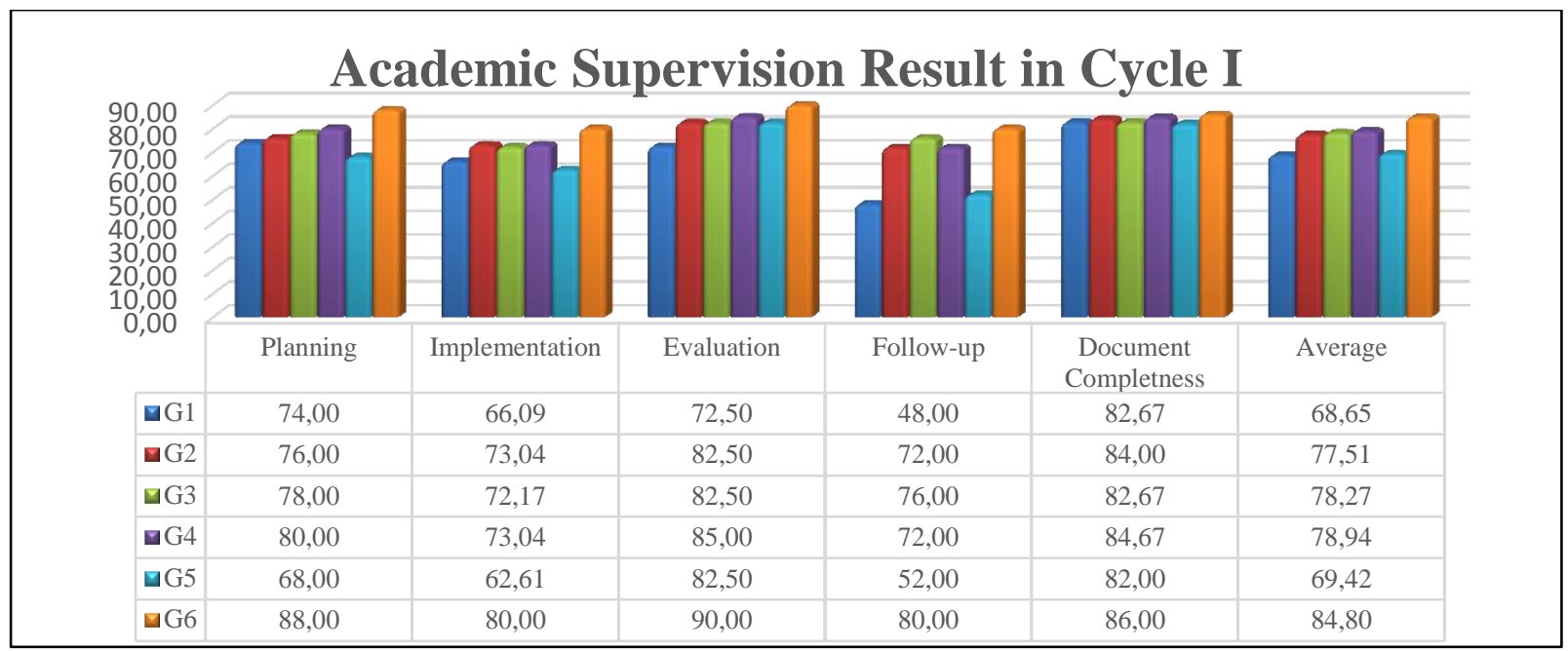

Figure 1: Teacher Academic Supervision Results Related to Teacher Performance in Learning

Based on Figure 1 above, it can be seen and analyzed that the performance of mathematics teachers are:

a) Phase of activities developing and compiling a learning plan

Mathematics teachers with G5 and G1 codes scored $<75$, in this condition the teachers need to be motivated. G5 and G1 so far have not made their own lesson plans but rather downloaded RPPs, so they do not understand what content is contained in the RPPs, indicators or aspects of planning that need to be improved are related to determining appropriate learning models and determining the learning media to be used.

b) Stage of learning implementation activities

Teachers with the code G1, G2, G3, G4, and G5 still get a value $<75$. Indicators that need to be improved in making apperception in the implementation of learning, namely preparing questions that relate previous knowledge to the material to be taught, inviting students to actively find concepts related to the material being taught - it can be through Student Activity Sheets (LAS) -, the teacher always explains the learning material. The average teacher uses the lecture method, and still finds the mathematics teacher who teaches is not the same as the learning model in the lesson plan. The media used in learning only uses power points that cannot interact both ways. a professional teacher is required to be able to develop and create learning media as a form of increasing the competence and innovative power of teachers. From this data it can be said that there are still many teachers who need to be motivated to develop creative and innovative learning media in accordance with teaching material. Teachers rarely facilitate students to carry out application or application activities in daily life. All mathematics teachers have not provided facilities for students to showcase the products produced, because in mathematics they tend to be difficult to produce a product. At the end of the learning process the teacher does not give the opportunity for students to reflect on the learning experience that has been done and for further improvement of learning. So they rarely 
evaluate what the advantages and disadvantages when carrying out learning. Some teachers in concluding the results of learning that have been done do not involve students, there are even teachers who do not do the activities of concluding, but immediately end the learning and give assignments. This happens because the time available is used up by students to only work on the worksheet. For this reason, it is necessary to direct the teacher to draw conclusions before class ends.

c) The activity phase of assessing student learning outcomes is only carried out by teachers with a G1 code grade $<75$. In G1 teachers, the aspect that must be improved in assessing student outcomes is that the teacher has not conducted the activity of analyzing the assessment results based on the level of difficulty that categorizes easy questions, moderate and difficult, distinguishing features, validity (the suitability of the questions and indicators of ability to be measured), and reliability. As a result, daily test questions and other exam questions made tend to be difficult. The types of assessments made by teachers in developing assessment instruments are still less diverse, forms of daily test questions always use essay questions and there are still questions that are not in accordance with predetermined learning indicators. Teachers are still focused on results-oriented assessment techniques, while the current educational demands of a teacher need to assess the student's process. Therefore, the process carried out by students actually provides the work they have done. The activity phase carries out the follow-up of the results of the student learning outcomes assessment

d) Mathematics teacher with codes G1, G2, G3, G4, and G5 who have grades <75. All aspects / indicators in implementing follow-up learning outcomes of students need to be improved, namely: (1) Identification of the need for follow-up assessment results. There are still many teachers who have not been able to identify the need for follow-up. Therefore, in the next cycle (cycle II), the teacher is invited to discuss the importance of the implementation of the follow-up. (2) It is necessary to arrange a follow-up program for the results of the assessment. Teachers who have not been able to compile a follow-up program need to be included in workshops or be guided by researchers in the preparation of a follow-up program. (3) There must be a follow-up because there are still many teachers who have not carried out the follow-up on the results of the assessment, the researcher provides continuous motivation and guidance to the teachers in order to carry out the results of the assessment. This effort must be made, because the teachers have not yet followed up on the results of the assessment, so the completion cannot be proven. For this reason, researchers provide motivation and guidance continuously to these teachers. (4) There needs to be a follow-up evaluation of the results of the evaluation program. (5) There needs to be an analysis of the results of the evaluation of the follow-up program for the results of the assessment because the analysis conducted by the teacher is still small. Those who did not analyze the results of the evaluation of the follow-up program were teachers who did not carry out an evaluation of the results of the follow-up assessment. For this reason, researchers provide motivation and guidance continuously to these teachers.

e) The activity phase completes the administration of learning

All mathematics teachers get grades $>75$. Even though all mathematics teachers score $>75$, there are learning documents that must be improved, including aspects of the mapping of Competency Standards (SK) and Basic Competencies (KD). Some teachers make the SK and KD collection from downloading results, so they do not understand the material or KD collection. Some teachers are less able to analyze which BC is at the application level. In the assessment document, the aspect that must be improved is the document of analysis of the results of the repetition. Some teachers only have an analysis of the results of the Final Semester Assessment (PAS) course, but the daily tests are not analyzed. Furthermore, in the improvement and enrichment program, almost all teachers make repairs or remidial programs only for students who have not yet completed learning, but do not make enrichment programs for students who have completed or meet the specified KKM. Another assessment document that needs to be improved is the creation of the TT and KMTT programs. In 
fact, personal development documents also need improvement. On average, six mathematics teachers only write Classroom Action Research (CAR).

In the self-activity document that needs to be improved, especially in mathematics teachers with the G5 code is the discipline of working hours. The finger print results of the teacher showed that teachers with the G5 code each month were late to school more than five times.

Table 3: Average Results of Teacher Performance in Learning Based on Academic Supervision in Cycle 1

\begin{tabular}{cccc}
\hline Name & Average & Predicate & Description \\
\hline G1 & 68,65 & C & Average \\
G2 & 77,51 & B & Good \\
G3 & 78,27 & B & Good \\
G4 & 78,94 & B & Good \\
G5 & 69,42 & C & Average \\
G6 & 84,80 & B & Good \\
\hline
\end{tabular}

Table 3 shows that the average performance of mathematics teachers in learning is based on the results of supervision of both categories (B). It's just that, there are still math teachers with G1 and G5 codes that score $<75$ with $C$, in good enough category. If translated as a percentage, cycle 1 shows $33.33 \%$ of mathematics teachers whose performance is still quite good. Meanwhile, mathematics teachers with codes G2, G3, G4, and G6 obtained an average performance of $>75$, either in the category of good or predicate B. The percentage of performance of the mathematics teacher who was categorized as good was $66.67 \%$. This shows that not all mathematics teachers' performance in learning is categorized as good so it needs to be improved

4) Reflection

Improving the performance of mathematics teachers in learning in high school in the first cycle needs to be improved, because not all mathematics teachers have good performance in learning outcomes. In the process of coaching activities obtained information from the observations as follows:

a) There are still teachers who must be motivated in making the Learning Implementation Plan (RPP). The lesson plan should be, not from someone else or downloaded on the internet (which sometimes has not been edited to make adjustments).

b) There are teachers who tend to only use lecture learning methods.

c) The teacher is still not motivating the students to be more active and enthusiastic during the learning process.

d) Teachers are not optimally utilizing and developing learning media.

e) There are still teachers who have not disciplined the administration of learning.

f) There are still teachers who have not done the enrichment program.

g) Teachers do not carry out a follow-up assessment of student outcomes.

Teacher Academic Supervision Findings Related to Teacher's Work Achievement in Learning in Cycle II

Based on the results of the previous teacher's performance evaluation analysis, in the first cycle, apparently not all mathematics teachers showed good performance. Therefore, in the second cycle, researchers conducted supervision by changing the approach from a passive supervision model to a more active supervision, a collaborative approach. Researchers collaborate with supervisors to supervise mathematics teachers openly, placing themselves as partners of teachers, so that during and after the supervision process there is a warm discussion, they give input to each other and the teacher is openly willing to make improvements. 
Following are the stages of academic supervision of mathematics teachers in learning in cycle II:

1) Planning

Planning in cycle II includes designing improvements based on deficiencies and problems that occur in cycle I. At this meeting researchers, supervisors and all mathematics teachers discuss aspects that need to be improved by the mathematics teacher. In a way that is familial, open and relaxed, complementary, teachers are more motivated to improve learning implementation plans, optimize teaching and learning processes, carry out assessments and follow up on student learning outcomes, and complete various learning administration documents. Supervision was carried out in the second cycle in November 2019.

2) Implementation

- The implementation of cycle II is carried out in November with the following activities:

- Supervisors motivate mathematics teachers the importance of improving teacher performance in learning.

- Supervisors convey the schedule of teachers who carry out academic supervision.

- Supervisors hold discussions about matters relating to the implementation of academic supervision if there is something that is not yet understood.

- The supervisor gives feedback or feedback to the mathematics teacher implementing the learning.

- The supervisor concludes the activities that have been carried out jointly between the supervisor and the mathematics teachers.

3) Observation

Researchers and supervisors make observations through academic supervision conducted outside and in the classroom. Observe all events that occur, starting from how enthusiastic the teachers of mathematics complete the various deficiencies of learning and assessment tools, carry out an attractive teaching and learning process with enthusiasm, end measurable learning, until they follow up on the results of the assessment, in the form of improvement and enrichment programs.

At this stage, the researcher always discusses with the supervisor what is happening and what the teacher is doing. One time researchers also communicated with mathematics teachers who were and had carried out their assignments. Researchers communicate with students who are and have finished following the process of teaching and learning mathematics, related to what is felt by students with the teacher's behavior, changes in the learning atmosphere, ease of understanding mathematics through learning done by the teacher, and learning outcomes obtained currently compared to before. From the observations and communication of researchers with supervisors, mathematics teachers and students show the learning process takes place in an optimal, attractive, innovative. Students were satisfied with the learning process, easier and faster in understanding the mathematics studied, the results of the mathematics learning post test also showed very encouraging values.

The results of the assessment conducted by researchers and supervisors on the performance of mathematics teachers in learning in cycle II are as follows: 


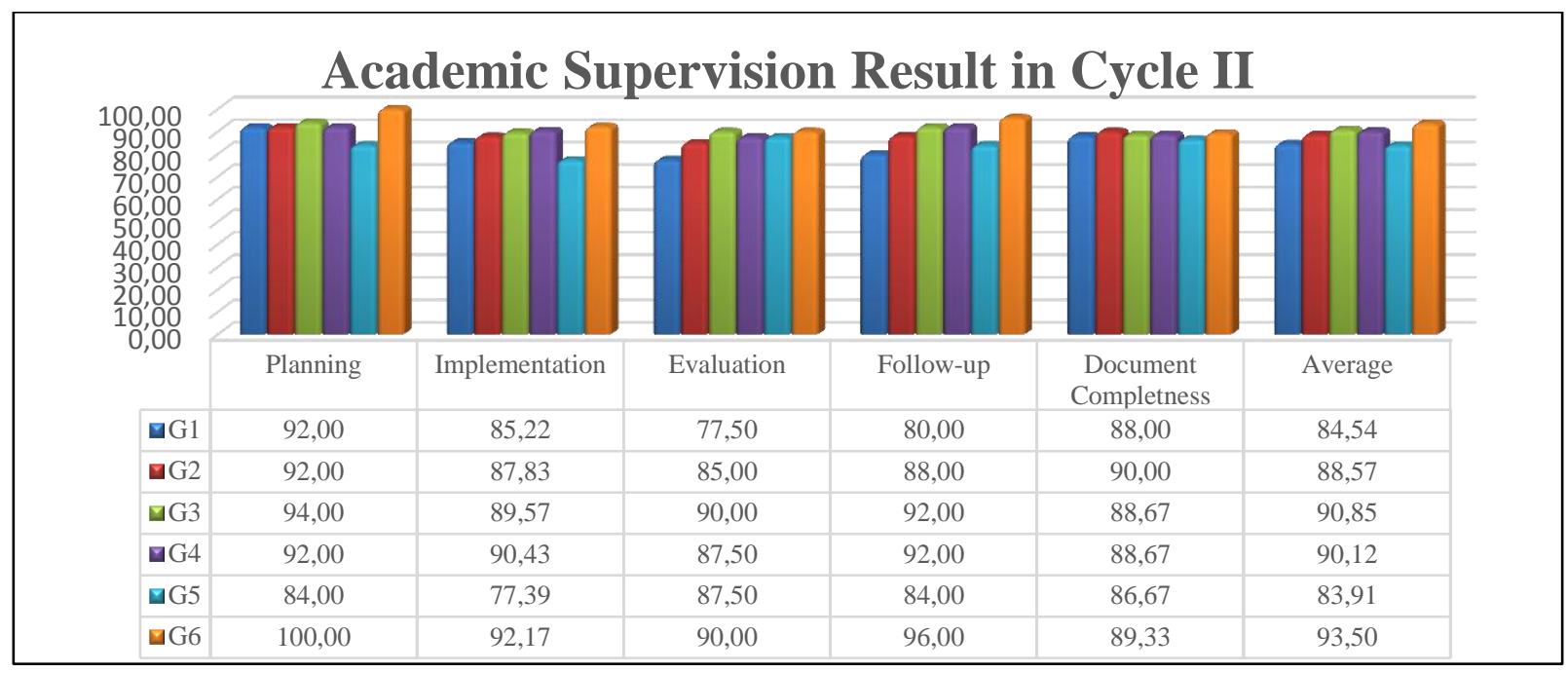

Figure 2: Teacher Academic Supervision Results Related to Teacher Performance in Learning

Figure 2 shows that mathematics teacher performance achievements with code G1, G2, G3, G4, G5, and G6 in developing and compiling learning plans, implementing Teaching and Learning Process (PBM), evaluating student learning outcomes, implementing follow-up activities to assess results learning of students, and in completing the administration made, all mathematics teachers have scored $>75$. This shows a significant increase in the performance of teachers in learning in cycle II. This condition needs to be maintained because good mathematics teacher performance can support good student learning outcomes and improve the quality of high school education.

Table 4: Average Results of Teacher Performance in Learning Based on Academic Supervision

\begin{tabular}{cccc}
\hline Name & Average & Predicate & Descriptio \\
\hline G1 & 84,54 & B & Good \\
G2 & 88,57 & B & Good \\
G3 & 90,85 & A & Very Good \\
G4 & 90,12 & A & Very Good \\
G5 & 83,91 & B & Good \\
G6 & 93,50 & A & Very Good \\
\hline
\end{tabular}

Table 4 shows that the average performance of mathematics teachers in learning based on the results of academic supervision in cycle II, all mathematics teachers with codes G1, G2, G3, G4, G5, and G6 got> 75. The performance of mathematics teachers in learning based on the results of teacher supervision with the code G1, G2, and G5 get the predicate B with good categories. While the teacher's performance in learning based on the results of the teacher's supervision with the code G3, G4, and G6 received the title A with a very good category. This indicates that there is a significant increase in the performance of mathematics teachers in learning.

4) Reflection

Compared to Cycle I, the application of academic supervision in Cycle II has increased. The results of the supervision of the performance of mathematics teachers in learning have all improved. An important task in the future is to maintain and continue to optimize the performance achievements that have been made with the aim that the quality or quality of education in high school can be maintained.

\section{RESULT, DISCUSSION, AND SUGGESTIONS}

Based on the above research results, this action research stopped until the second cycle, because the results obtained in the second cycle which is a follow-up of the results of reflection in the first cycle, were 
very satisfying. The success of the action in the second cycle lies in academic supervision using a collaborative approach which turned out to have a significant increase compared to the first cycle that uses a passive approach. The improvement in mathematics teacher performance is illustrated in Figure 3 as follows:

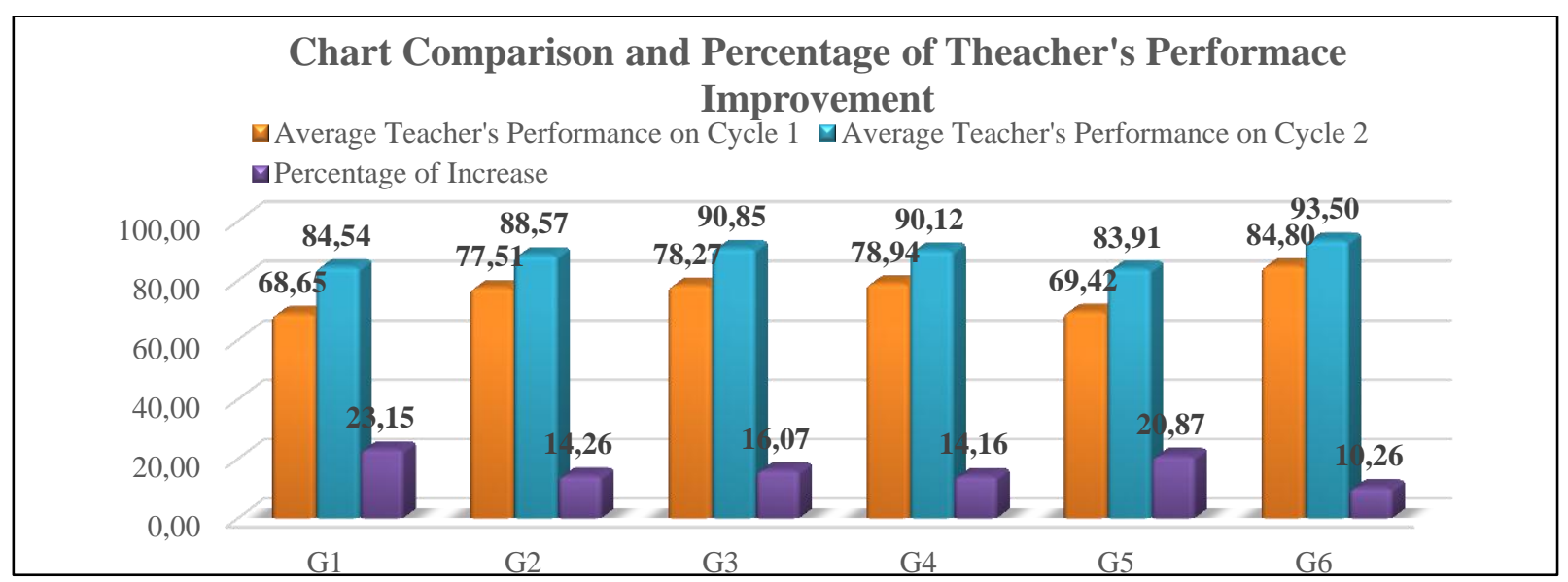

\section{Figure 3: Comparison and Percentage of increase in Academic Supervision Results Regarding Teacher Performance in Learning in Cycles I and II}

Based on Figure 3, it can be seen that the teacher with G1 code has the highest percentage increase in performance in learning by $23.15 \%$. Teachers with the G5 code ranked second in an increase in learning performance by $20.87 \%$. Teachers with the G3 code ranked third in an increase in learning performance by $16.07 \%$. Teachers with G2 and G4 codes experienced an increase in teacher performance in learning almost the same by $14.26 \%$ and $14.16 \%$. While teachers with the G6 code experienced an increase in teacher performance by $10.26 \%$. The highest increase in performance in the G1 code teacher is allegedly because in addition to being a supervisor, he also acts as a supervisor for mathematics teachers. Therefore, he has the ease in receiving advice from fellow supervisors to overcome the difficulties that arise. In addition, the approach taken by the supervisor is collaborative, so as to allow assessors and teachers to be able to provide input to each other openly, and jointly correct their shortcomings. With this collaborative approach also makes mathematics teachers help each other provide solutions in solving problems that need to be fixed. 


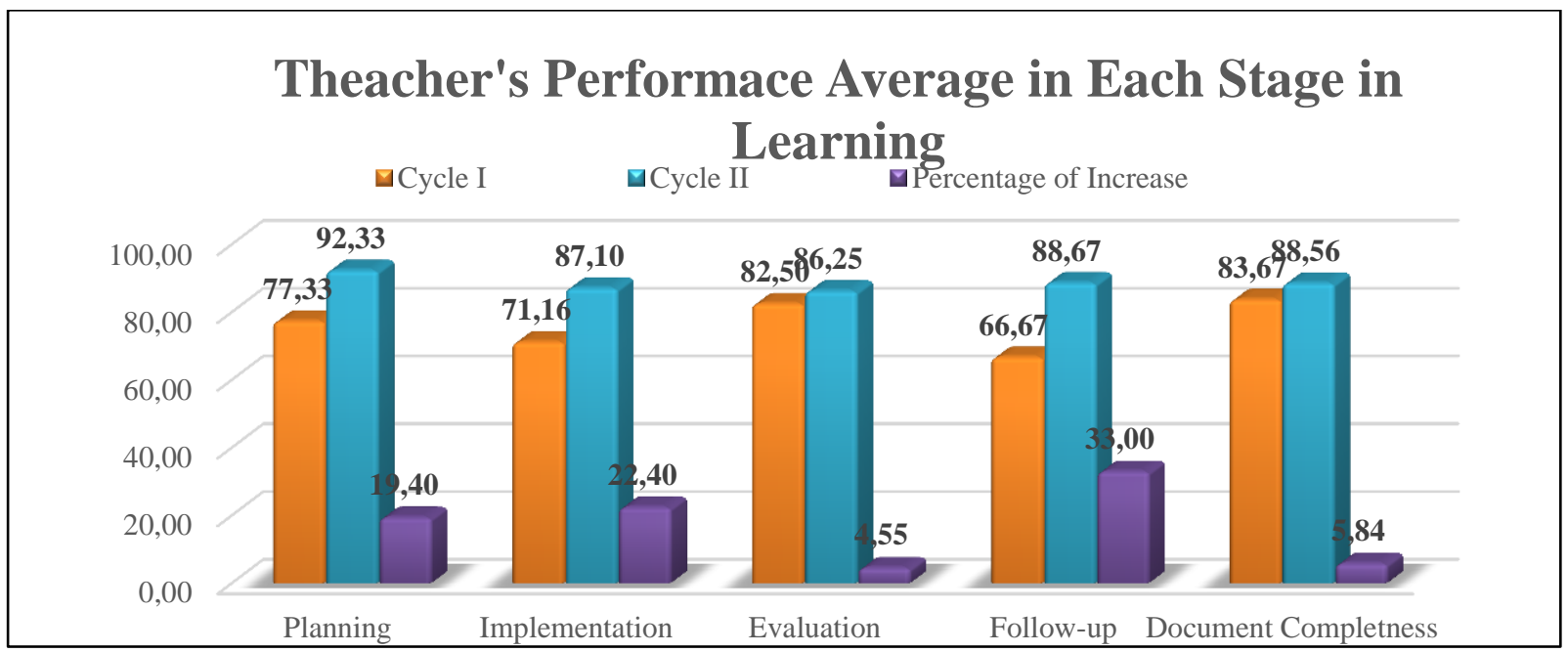

Figure 4: Comparison and Average Percentage of Teacher Performance in All activities in learning the results of supervision in cycle I and cycle II

Figure 4 shows that the highest increase in mathematics teacher performance occurred at the stage of follow-up of $33 \%$. The second increase occurred in the implementation of learning activities by $22.40 \%$. This proves that the implementation of academic supervision by using a collaborative approach makes teachers aware of the importance of following up on assessment results, and makes the learning process even better. A higher quality learning process that is followed up with various appropriate improvement and enrichment programs, will have an effect on improving student learning outcomes.

The results of the action research that have been carried out by researchers starting from the first cycle to the second cycle shows the following findings:

1) The achievement of high school mathematics teacher performance in learning increases. This can be seen from Graph 3 which shows that the performance of six mathematics teachers in learning all improved. The supervised mathematics teacher's performance focuses on completing teacher administration, performance achievements in developing and compiling learning plans, performance achievements in the teaching and learning process, performance achievements in evaluating student learning outcomes, and performance achievements in implementing follow-up activities evaluating student learning outcomes . Improved performance of mathematics teachers due to good collaboration among fellow mathematics subjects in one school MGMP, teachers who are still experiencing difficulties with teachers already have solutions in overcoming problems in learning, as well as guidance and guidance conducted by researchers and supervisors who are also teachers mathematics. In addition, academic supervision is carried out with a collaborative approach, so that all mathematics teachers have a variety of characteristics that can work collaboratively, have the motivation to reflect on their performance, and share experiences with their peers.

2) The second finding is that the performance of mathematics teachers increases in the implementation of learning in the classroom. Basically the teacher is a person who is able to teach, but not necessarily all teachers can carry out learning that is creative, fun, and oriented to students. In this action research initially, on average only 71.16 teachers were able to carry out fun and interactive learning, even though the classroom conditions and conditions were still rather awkward, because researchers and supervisors participated in the teaching and learning process in the classroom. But then in the implementation of learning in the second cycle, the percentage of teacher success in implementing learning that is creative, fun, and oriented to students increased by $22.40 \%$ to 87.10 . The percentage acquisition indicates that an increase in average teacher performance in the teaching and learning process.

3) The third finding shows the achievement of mathematics teacher performance increases in following up assessing student learning outcomes. In the action research conducted in high school, the results obtained indicate that the implementation of academic supervision with a collaborative approach has a positive impact on teachers in following up assessing student learning outcomes. At the beginning of the 
implementation of academic supervision, there are still many teachers who have difficulty in following through assessing student learning outcomes. The initial assessment showed an average of 66.67 difficulties. This is because the teacher does not have much time in arranging, implementing and evaluating the follow-up program of student learning outcomes, because the average number of teaching hours for mathematics teachers is very much at 36 hours per week. This problem can be overcome by doing a follow-up program on Saturdays, outside class hours. Next to the follow-up in the process of assessing student learning outcomes in cycle II, the percentage increased by $33 \%$ to 88.67 . The percentage acquisition indicates that there is an increase in the average performance of teachers in following up assessing the learning outcomes of teacher students.

4) The fourth finding shows the average performance of mathematics teachers in preparing learning plans increases. In school action research, the results obtained indicate that the average performance of mathematics teachers in planning activities in the first cycle was only 77.33. Actually the value has reached the benchmark value of success of a teacher that is greater or equal to $\geq 75$. However, there are only two mathematics teachers who achieve a value of $\geq 75$. So that improvements were made in the second cycle which showed a percentage increase of $19.40 \%$ to 92,33 . This is because teachers initially did not make Learning Implementation Plans (RPPs) themselves, most of them only downloaded and copied so they did not really understand and found it difficult to develop lesson plans. However, after receiving guidance and guidance by supervisors and mutual assistance between mathematics teachers in finding solutions during reflection in cycle I, so that all teachers understand the essence of developing lesson plans.

These findings prove that the establishment of an appropriate school principal's academic supervision policy, and the selection of appropriate strategies, approaches and supervision models by supervisors, determine the success of supervision. Because in essence, supervision is not only for photographing teacher performance, in order to obtain a complete picture of the teacher's performance profile, which is then poured in the Teacher Performance Evaluation Sheet (PKG) and Employee Performance Targets (SKP) each year, in the interest of increasing promotion; but also at the same time improving its performance.

The principal's policy by involving more senior teachers to supervise junior teachers, the principal only supervises the most senior teachers, and supervisors only supervise the principal, is the right policy and step. The involvement of all school components in implementing supervision encourages harmonious and collaborative academic supervision, which is more effective and efficient. Each teacher better understands his condition, character, ability so that a harmonious relationship occurs. This harmony makes the teachers open to be assessed, given input, and even does not hesitate to convey their weaknesses and various obstacles encountered. Supervisors also place themselves as partners, friends, colleagues, not superiors, and have never crossed their hearts to find fault, so they can provide input freely. This harmonious relationship makes the implementation of supervision take place in an elegant manner, because they need each other, give and take each other, intense discussions take place. As a result, supervisors can portray teacher performance appropriately, improvement in teacher performance can also be improved. With improved performance, it will certainly correlate to improving the quality of the learning process and student learning outcomes.

Proving the effectiveness of supervision implementation has been carried out by various researchers, but it has not yet revealed the main root problems and how the supervision process is carried out in full so that it is more effective, can improve teacher performance.

The results of Yunus's (2016) research showed an increase in the ability of high school teachers to teach before treatment and after treatment with a significant level of 0.012 , so that the development of the Academic Supervision Based Self Evaluation (SABED) model was declared effective in increasing the professional competence of high school teachers. Hardono and Haryono's (2017) research proves that there is an influence of the principal's leadership in carrying out academic supervision on work motivation and teacher performance both partially and simultaneously.

Damayanti (2016) recommended the need for a synergistic combination of Artistic Academic Supervision and Cooperative Development in order to provide positive changes towards improving teacher performance. Nurpuspitasari's (2019) research found that the effectiveness of teacher learning would be maximized, if there were efforts to improve academic supervision of school principals and school culture. Juaini and Made (2016) prove the model of academic supervision based on excellent service is effective to 
improve the performance of high school teachers. Researcher Astuti (2017) shows that academic supervision by the school principal through discussion can improve the administration ability of teachers in conducting learning assessments.

Subaidi's (2019) research also shows the academic competence and communication of principals in conducting academic supervision have a positive impact on improving teacher competence, both personal, social, professional, and pedagogical competencies. Sepriadi and Ahmad's (2017) research shows that there is a positive and significant influence on the leadership of school principals as academic supervisors on teacher performance, there is also an increase in teacher knowledge, teacher personality, devotion, and teacher professional development. Hazli and Saputra (2019) proved the supervision of school supervisors and principals had a positive and significant effect on teacher performance. The results of the same study had previously been carried out by Kusmanto (2016), proving managerial supervision using effective group techniques in increasing the competency of principals supervision.

Efendi's (2016) research also proved that principal's supervision had a positive and very significant effect on lecturer performance. Juwaidin's (2016) research results show changes in the professional competence of teachers after academic supervision, as seen in changes in teaching patterns in the classroom, learning preparation instruments.

The novelty of my research, the researcher found, turned out to be the effectiveness of the academic supervision process with a collaborative approach shown by the harmonious relationship between supervisors and supervised ones. The instruments contained in the supervision guidelines are indeed used as a standard and evaluation form, but their implementation is more flexible. So that the supervisior can act and act according to the conditions and conditions that are supervised. Each feels need each other, wants to learn and is willing to give. There is no mutual suspicion, which is complementary, encouraging awareness to improve itself.

To avoid the subjectivity of the assessment, each supervisor makes a written report as it is, even the report is also previously known and discussed with the supervised teacher. Each supervisor's report is presented in the forum, consisting of assessors from teachers, principals and supervisors. Together they study, clarify and discuss the truth. Through this forum, the truth of the results of supervision can be justified, the supervised teachers also feel proud of the results of the supervision obtained, while still trying to improve their performance.

The academic supervision model with a collaborative approach like this if continued to be cultivated in schools, will have implications not only for continuous improvement in the quality of student learning processes and outcomes, but also in the realization of harmonious work, which certainly has an impact on improving the performance of the institution. The progress of the institution can be achieved, the trust of the community and users of lulusa is increasing, so that the existence of the institution is increasingly surviving.

Implementation of Academic Supervision with a collaborative approach can help develop and improve the performance of mathematics teachers in learning in high schools. Teacher performance in supervised learning consists of teacher performance in completing teacher administration, teacher work achievement in developing and compiling learning plans, teacher work performance in implementing Teaching and Learning Process (PBM) activities, teacher work performance in evaluating student learning outcomes, and the teacher's work achievements in implementing follow-up activities on the results of student learning evaluations. In the activities, the performance of mathematics teachers in developing and compiling learning plans increased by $19.40 \%$. The performance of mathematics teachers in implementing learning has increased by $22.40 \%$. Mathematics teacher performance achievements in the implementation of student learning outcomes evaluation increased $4.55 \%$, from the performance of 82.50 to 86.25 . This increase exceeds the target set by researchers, which is at least 85 . Teacher performance in implementing follow-up activities of student assessment results increased $33.00 \%$. The performance of mathematics teachers in completing the administration of learning increased at $5.84 \%$. The results of this study prove, a collaborative approach in academic supervision is very effective, can accelerate the increase in performance of all teacher assignments. The proof can be seen in every task, even exceeding the minimum target. Because it is effective, in implementing academic supervision, the application of collaborative approaches must continue to be developed, so that the continuity of teacher performance improvement can be guaranteed.

The researcher suggests, the collaborative supervision approach is not only carried out on mathematics teachers, but all subject teachers in schools. Supervisors in conducting supervision must also be 
willing to change their paradigm. This is where synergy between supervisors, principals and supervisors is assigned by principals to supervise. In this way the common perception and togetherness steps can be formed, the relationship between supervisors and supervised teachers is also becoming more familiar and open, and consequently making things easier, so that institutional performance is also increasing, school progress can be achieved.

\section{REFERENCES}

Ajasan, N. (2016). Efektivitas Pelaksanaan Supervisi Akademik oleh Kepala Sekolah dalam Meningkatkan Kinerja Guru di SMK Negeri 1 Meulaboh. Jurnal Administrasi Pendidikan : Program Pascasarjana Unsyiah, 4(3), 1-9.

Alghifari, E. S., Sunandar, S., Yuliejantiningsih, Y., Nurkolis, N., Putri, N., Asri, Y., Sunanik. (2016). Manajemen Mutu dalam Pengembangan Kompetensi Guru. Tarbawi: Jurnal Keilmuan Manajemen Pendidikan, 3(1), 32-41.

Astuti, S. (2017). Supervisi Akademik untuk Meningkatkan Kompetensi Guru di SD Laboratorium UKSW. Scholaria : Jurnal Pendidikan Dan Kebudayaan, 7(1), 49.

Basri, R., Bakar, N. A., Foo, D., Fooi, S., \& Pendidikan, F. P. (2017). Hubungan Kepimpinan Pengajaran Pengetua dengan Pencapaian Akademik Pelajar. International Research Journal of Education and Sciences (IRJES), 1(1), 2550-2158.

Dalawi. Zakso, Amarazi. Radiana, U. (2019). Pelaksanaan Supervisi Akademik Pengawas Sekolah Sebagai Upaya Peningkatan Profesionalisme Guru SMP Negeri 1 Bengkayang. Journal of Chemical Information and Modeling, 53(9), 1689-1699.

Damayanti, W. (2016). Peningkatan Mutu Kinerja Guru Melalui Supervisi Akademik di SMK Negeri 1 Salatiga Menghadapi PKG 2016. Jurnal Pendidikan Ilmu Sosial, 26(1), 80-86.

Efendi, Y. (2016). Performance Kinerja Dosen di lingkungan Universitas Riau Kepulauan ditinjau dari aspek Supervisi Dekan pada tahun 2012-2013. JURNAL DIMENSI, 3(1).

Fahmi, C. N., Nurliza, E., AR, M., \& Usman, N. (2018). Pelaksanaan Supervisi Akademik dalam Meningkatkan Kompetensi Guru Sekolah Dasar. JURNAL SERAMBI ILMU, 30(2), 104.

Faridah, J., \& Mohd Izham, M. H. (2017). Kepimpinan teknologi pengetua dan hubungannya dengan prestasi akademik sekolah di Malaysia. International Journal of Education, Psychology and Counseling, 2(5), 215-230.

Fathurrohman, Pupuh, \& Suryana, A.A. (2011). Supervisi Pendidikan dalam Pengembangan Proses Pengajaran. Bandung: Rafika Adita.

Guntoro, David. F., Sumaryanto, Totok., A. R. RC. (2016). Pengembangan Model Supervisi Akademik Berbasis Web. Educational Management: Major Themes in Education, 5(2), 122-128.

Hadis, Abdul, \& B. Nurhayati. (2014). Manajemen Mutu Pendidikan. Bandung: Alfabeta.

Hardono, Haryono, \& Yusuf, A. (2017). Kepemimpinan Kepala Sekolah, Supervisi Akademik, dan Motivasi Kerja dalam Meningkatkan Kinerja Guru. Educational Management, 6(1), 26-33.

Hazli, H., \& Saputra, R. R. (2019). Analisis Pengaruh Supervisi Pengawas Dan Supervisi Kepala Sekolah Terhadap Kinerja Guru Di Madrasah Ibtidaiyah Kecamatan Sukau Lampung Barat. Publikasi Pendidikan, 9(1), 62.

Jamal, F. (2018). Kompetensi Pedagogik Guru Matematika Menengah Pertama Negeri Kecamatan Johan Pahlawan Kabupaten Aceh Barat. MAJU : Jurnal Ilmiah Pendidikan Matematika, 5(1), 108-119.

Juaini, M., Rusdarti, \& Made, S. (2016). Supervisi Akademik Berbasis Pelayanan Prima Pada Guru SMA Di Kabupaten Lombok Timur. Educational Management, 5(1), 55-63.

Jumadiah, N., Nurdia, O., Rahmi, R., \& Rhoni, R. (2016). Implementasi Supervisi Akademik Kepala MIS Batusangkar. Jurnal Manajemen, Kepemimpinan, Dan Supervisi Pendidikan, 1(2), 230-878.

Juwaidin. (2016). Supervisi Akademik di SMA Negeri 1 Lambitu. Jurnal Ilmiah Educational Management, 7(1), 1211-1219.

Kelana, Narwan Sastra. (2020). "Dongkrak Kualitas Pendidikan, Mendesak Dirumuskan Indikator UKG". Siedoo.com, 9 Maret 2020.

Kurniawan, D., Dwikurnaningsih, Y., \& Sulasmono, B. S. (2018). Evaluasi Program Supervisi Akademik di PAUD Swasta. Kelola: Jurnal Manajemen Pendidikan, 5(2), 107-123. 
Kusmanto, B. (2016). Peningkatan Kompetensi Supervisi Kepala Sekolah Melalui Supervisi Kelompok di Sekolah Dasar. Manajemen Pendidikan, 11(1), 17.

Lalupanda, E. M. (2019). Implementasi Supervisi Akademik Untuk Meningkatkan Mutu Guru. Akuntabilitas Manajemen Pendidikan, 7(1), 62-72.

Lavigne, A. L., \& Chamberlain, R. (2017). Teacher evaluation in Illinois: School leaders' perceptions and practices. Educational Assessment, Evaluation and Accountability, 29(2), 179-209.

Lawrence, K., \& Bouchamma, Y. (2014). Teacher Supervision Practices and Characteristics Of in-School in Uganda. Educational Assessment Evaluation and Accountability, 26 (1), 51-72.

Leniwati, L., \& Arafat, Y. (2017). Implementasi Supervisi Akademik Kepala Sekolah untuk Meningkatkan Kinerja Guru. Jurnal Manajemen, Kepemimpinan, Dan Supervisi Pendidikan, 2(1), 230-856.

Majid, A. (2018). Penerapan Coaching untuk meningkatkan kompetensi kepala sekolah dalam supervisi akademik pada SMP Binaan Dinas Pendidikan kota Banjarmasin. Lentera: Jurnal Pendidikan, 13(1).

Maya Putri, M. A., Khairuddin. (2016). Pelaksanaan Supervisi Pengajaran dalam Meningkatkan Proses Belajar Mengajar di SMA Negeri 5 Kota Banda Aceh. Jurnal Administrasi Pendidikan: Program Pascasarjana Unsyiah, 4(3), 89-99.

Merukh, N., \& Sulasmono, B. S. (2016). Pengembangan Model Supervisi Akademik Teknik Mentoring bagi Pembinaan Kompetensi Pedagogik Guru Kelas. Kelola: Jurnal Manajemen Pendidikan, 3(1), 30.

Nurpuspitasari, D., Sumardi, S., Hidayat, R., \& Harijanto, S. (2019). Efektivitas Pembelajaran ditinjau dari Supervisi Akademik Kepala Sekolah dan Budaya Sekolah. Jurnal Manajemen Pendidikan, 7(1), 762 769.

Paramita, Rahadian P.(2018). Rapor Guru dalam Hasil Uji Kompetensi. Lokadata, 27 November 2018.

Ramadhan, A. (2017). Pengaruh Pelaksanaan Supervisi Akademik Pengawas Sekolah dan Supervisi Kepala Sekolah Terhadap Kinerja Guru SMK Negeri di Kabupaten Majene. Journal of Educational Science and Technology, 3(2), 136-144.

Riski, Aulia. (2019). Supervisi Akademik Kepala Sekolah. Journal of Chemical Information and Modeling, 53(9), 1689-1699.

Sepriadi, S., \& Ahmad, S. (2017). Pengaruh Peran Kepala Sekolah sebagai Supervisor Akademik terhadap Kinerja Guru di SMK PGRI Tanjung Raja. Jurnal Manajemen, Kepemimpinan, Dan Supervisi Pendidikan, 2(1), 230-862.

Subaidi. (2019). Supervisi Akademik Kepala Madrasah dalam Meningkatkan Kinerja Guru pada Madrasah Tsanawiyah Nahdlatul Ulama Banat Kudus. JURNAL ISEMA: Islamic Education Menagement, 4(2), 113.

Sugiyono. (2015). Metode Penelitian Kombinasi (Mix Methods). Bandung: Alfabeta.

Susetya, B. (2017). Meningkatkan Kemampuan Guru dalam Menyusun Silabus dan lesson plan melalui Supervisi Akademik di SD N Gambiran Yogyakarta tahun 2016. TAMAN CENDEKIA: Jurnal Pendidikan Ke-SD-An, 1(2), 134.

Usman, N., AR, M., Nurliza, E., \& Fahmi, C. N. (2018). Pelaksanaan Supervisi Akademik dalam Meningkatkan Kompetensi Guru Sekolah Dasar. Jurnal Serambi Ilmu, 30(2r), 104-119.

Yunus, G., Lestari, W., Raharjo, T., (2016), Pengembangan Model Supervisi Akademik Berbasis Evaluasi Diri bagi Guru SMA. Educational Management, 5(1), 12-22.

Zubaidah, Neneng. (2019). Rata-rata Nilai Ujian Nasional SMA dan SMK Naik. DKI Jakarta. SINDONEWS.COM, 08 Mei 2019. 